\title{
Combustion and gasification characteristics of chars from raw and torrefied biomass
}

\author{
E.M. Fisher ${ }^{\mathrm{a}, *}$, C. Dupont ${ }^{\mathrm{b}}$, L.I. Darvell ${ }^{\mathrm{c}}$, J.-M. Commandré ${ }^{\mathrm{d}}$, A. Saddawi ${ }^{\mathrm{c}}$, J.M. Jones ${ }^{\mathrm{c}}$, M. Grateau ${ }^{\mathrm{b}}$, \\ T. Nocquet ${ }^{\mathrm{b}}$, S. Salvador ${ }^{\mathrm{e}}$ \\ a Sibley School of Mechanical and Aerospace Engineering, Upson Hall, Cornell University, Ithaca, NY 14853, USA \\ ${ }^{\mathrm{b}}$ Commissariat à l'Energie Atomique et aux Energies Alternatives, LITEN/DTBH/LTB, Grenoble, France \\ ${ }^{\mathrm{c}}$ School of Process, Environmental and Materials Engineering, University of Leeds, Leeds, LS2 9JT, UK \\ ${ }^{\mathrm{d}}$ CIRAD, UPR 42 Biomasse Energie, Montpellier, France \\ e Université de Toulouse, MINES ALBI, RAPSODEE, FRE CNRS 3213, Campus Jarlard, route de Teillet, 81013 ALBI CT CEDEX 09, France
}

Keywords:

Torrefaction

Oxidation

Gasification

Biomass

Kinetics

\begin{abstract}
A B S T R A C T
Torrefaction is a mild thermal pretreatment $\left(\mathrm{T}<300^{\circ} \mathrm{C}\right)$ that improves biomass milling and storage properties. The impact of torrefaction on the gasification and oxidation reactivity of chars from torrefied and raw biomass was investigated. Thermogravimetric analysis was used to study the differences in $\mathrm{O}_{2}$ and steam reactivity, between chars prepared from torrefied and raw willow, under both high- and low-heating-rate conditions. High-heating-rate chars were prepared at $900{ }^{\circ} \mathrm{C}$ with a residence time of $2 \mathrm{~s}$. Lowheating-rate chars were prepared with a heating rate of $33^{\circ} \mathrm{C} / \mathrm{min}$, a maximum temperature of 850 or $1000{ }^{\circ} \mathrm{C}$, and a residence time of $30 \mathrm{~min}$ or $1 \mathrm{~h}$, respectively, at the maximum temperature. Pretreatment by torrefaction consistently reduced char reactivity. Torrefaction's impact was greatest for high-heatingrate chars, reducing reactivity by a factor of two to three. The effect of torrefaction on a residence time requirements for char burnout and gasification was estimated.
\end{abstract}

\section{Introduction}

Torrefaction is a mild thermal pretreatment that occurs below $300^{\circ} \mathrm{C}$ under an inert atmosphere. Under these conditions the initial biomass is converted mainly into a solid product whose properties are intermediate between coal and biomass. As described by Chew and Doshi (2011), the torrefied product has a brown color, decreased $\mathrm{H} / \mathrm{C}$ and $\mathrm{O} / \mathrm{C}$ ratios, and an increased energy density. In addition, it is hydrophobic, brittle and, in comparison to raw biomass, more easily fluidizable (Svoboda et al., 2009) and less prone to agglomerate (Chen et al., 2011). These properties give the torrefied product advantages over raw biomass for transportation, storage, milling and feeding. Hence, torrefaction appears as a very

\footnotetext{
* Corresponding author. Tel.: +1 607255 8309; fax: +1 6072551222 .

E-mail address: emfisher@cornell.edu (E.M. Fisher).
}

promising pretreatment for co-firing with pulverized coal in existing large industrial facilities and gasification in entrained flow reactors.

Biomass combustion or gasification consists of two partially overlapping processes: (1) the release of water and volatiles, i.e. pyrolysis (also known as volatilization or charring), followed by (2) the slower reaction of the solid residue (char) with oxygen or steam, respectively. As the second process is slower than the first, it has an important impact on reactor sizing, control and efficiency (Costa et al., 2003; Di Blasi, 2009; Dupont et al., 2011). Char properties depend strongly on pyrolysis conditions, especially on the heating rate during pyrolysis (Di Blasi, 2009). Although there is no one generally accepted definition of char reactivity, it is possible to determine a global char reactivity from mass loss histories, by defining it as the time derivative of the conversion. This global reactivity is influenced by the char surface area and surface accessibility as well as by intrinsic kinetic parameters. 
Two key attributes of torrefied biomass, in comparison to raw biomass, are relevant to char morphology and thus to char reactivity: the reduced amount of volatiles to be released during pyrolysis, and the different distribution of particle sizes produced during milling. Both of these differences are expected to be most influential under fast pyrolysis conditions, as described below.

When raw biomass is rapidly pyrolyzed, the resulting rapid release of volatiles deforms biomass structures and typically leads to higher macropore surface areas and thus to higher reactivities ( $\mathrm{Di}$ Blasi, 2009). It appears that torrefaction, which shifts volatiles release to the low-heating-rate torrefaction process, could reduce this effect, thus lowering the reactivity of high-heating-rate chars.

The typical distribution of particle sizes present in torrefied vs. raw biomass may also have an important effect. Pulverized woody biomass particles are typically $300 \mu \mathrm{m}$ or even larger in their small dimension, while pulverized coal particles are closer to $50 \mu \mathrm{m}$ (Tillman, 2000; Skeen et al., 2010). While industrial-scale size distribution data are not available for torrefied materials, it appears that pulverized torrefied biomass has a size distribution more comparable to that of coal than that of raw biomass (Bridgeman et al., 2010; Repellin et al., 2010). Transport limitations during heating are reduced for smaller particles, resulting in a higher effective heating rate. Although research in this area has been limited, initial particle size has been observed to have an impact on morphology of biomass chars (Avila et al., 2011) and on reactivity of coal chars (Zhu et al., 2008). Experimental particle size distributions in the present study (given below) reflect the anticipated differences between torrefied and raw biomass that will occur in full-scale devices.

Combustion kinetics of torrefied biomass have received little attention up to now (Bridgeman et al., 2010; Arias et al., 2008), and steam gasification kinetics have been studied only qualitatively to date (Couhert et al., 2009). In the current work, reactivities of several chars from torrefied and non-torrefied biomass are compared under oxidation and gasification conditions. Two different types of chars are studied: high-heating-rate chars formed under conditions representative of pulverized coal furnaces or entrained flow gasifiers, and low-heating-rate chars formed under conditions representative of moving grate combustors or low temperature reactors. The range of heating rates occurring in practical biomass conversion devices is discussed by Mehrabian et al. (2011).

\section{Experimental methods}

\subsection{Drying and torrefaction}

Short rotation coppice willow chips, harvested in 2008 and stored first in heaps, then in bags, until their use in spring 2010, were supplied by Rothamsted Research, Harpenden, UK. The chips were sieved to select those with their two smallest dimensions between 5.6 and $9.5 \mathrm{~mm}$, and then dried thoroughly at $110^{\circ} \mathrm{C}$ following a procedure similar to the European standard CEN/TS 14774. After drying, batches of $70 \mathrm{~g}$ of chips were stored in closed plastic bags until use.

A packed bed of chips in a 6-cm-ID reactor was placed in the central zone of a temperature-programmed furnace and torrefied under a gentle nitrogen flow of 0.8 standard liters per min (slpm). Batches of $70 \mathrm{~g}$ of willow were torrefied with the following imposed temperature program: ramp at $5^{\circ} \mathrm{C} / \mathrm{min}$ from room temperature to $150^{\circ} \mathrm{C}$; hold at $150^{\circ} \mathrm{C}$ for $45 \mathrm{~min}$; ramp at $5^{\circ} \mathrm{C} / \mathrm{min}$ to desired end temperature $\left(270\right.$ or $\left.290{ }^{\circ} \mathrm{C}\right)$; hold at end temperature for either 41 or $38 \mathrm{~min}$, giving a total time above $200{ }^{\circ} \mathrm{C}$ of approximately $60 \mathrm{~min}$. Temperatures were measured with several sheathed thermocouples inserted into the packed bed of biomass, and compared to the imposed temperature program. The actual temperatures lagged the set point temperatures by a few degrees during the ramp period. Also, measured peak temperatures differed from the set point maximum by as much as $15-22^{\circ} \mathrm{C}$, with temperatures above the set point near the downstream edge of the biomass bed, and below the set point near the upstream edge of the biomass bed. Mass losses during torrefaction were $23 \%$ and $37 \%$ on a dry basis, for the 270 and $290^{\circ} \mathrm{C}$ cases, respectively.

\subsection{Production and storage of chars}

Conditions for char production are summarized in Table 1 , which also gives a brief code name for each char, to be used below.

Torrefied or raw willow samples were milled in a Retsch PM 100 ball mill. Different milling regimens were used for the raw vs. the torrefied biomass; the milling regimen was chosen empirically to ensure that virtually all the material passed through a 1$\mathrm{mm}$ sieve. Raw biomass was processed at $450 \mathrm{rpm}$ for $1 \mathrm{~min}$, $525 \mathrm{rpm}$ for $1 \mathrm{~min}$, and $650 \mathrm{rpm}$ for $45 \mathrm{~s}$. Torrefied biomass was processed at $450 \mathrm{rpm}$ for $30 \mathrm{~s}$, followed by $650 \mathrm{rpm}$ for $45 \mathrm{~s}$. In all cases, samples were then passed through a 1-mm sieve. Sieved samples were stored in closed plastic bags until use; typical storage times were $1-2$ months.

The procedure for producing low-heating-rate (LHR) chars was the following: Three samples of sieved material were placed in nickel crucibles. Sample masses ranged between 0.91 and $1.32 \mathrm{~g}$. The crucibles were put inside a quartz reactor, which was placed in a furnace and purged for an hour at room temperature under a gentle nitrogen or argon flow. Next, with the inert flow continuing, the reactor contents were heated at $33^{\circ} \mathrm{C} / \mathrm{min}$ from room temperature to the desired peak temperature of either $1000^{\circ} \mathrm{C}$ or $850^{\circ} \mathrm{C}$. The reactor was held at the peak temperature for the desired time (60 or $30 \mathrm{~min}$, respectively), at the end of which the tube furnace was switched off. The inert flow was maintained for several hours as the tube furnace and contents cooled to $65^{\circ} \mathrm{C}$ or lower; then samples were removed and weighed.

Fractional mass losses during charring are listed in Table 1. Mass losses were repeatable to within $1.4 \%$.

High-heating-rate (HHR) chars were produced in a drop tube reactor, which is representative of the very high heat transfer encountered in industrial units. The reactor was fully characterized by Van de Steene et al. (2000), Commandré et al. (2005), and Dupont et al. (2008). It consists of an alumina tube of $2000 \times 75 \mathrm{~mm}(\mathrm{~L} \times \mathrm{ID})$, inserted into a vertical electric heater with three independent heating zones; the total isothermal reaction zone is $1 \mathrm{~m}$ long. The raw and torrefied willow particles were continuously fed by a controlled weighing system at a flow rate of $0.5 \mathrm{~g} / \mathrm{min}$, transported in a 2-slpm nitrogen carrier gas, and injected into the reactor through a water-cooled feeding tube. A dispersion dome was placed at the outlet of the feeding tube to distribute the solid particles homogeneously over the reactor cross section. Another nitrogen stream passed through a pre-heater to reach the reactor temperature of $900{ }^{\circ} \mathrm{C}$ and then met the mixture of cold wood particles and nitrogen carrier stream at the dispersion dome. The total nitrogen flow rate was $18 \mathrm{slpm}$. A water-cooled sampling probe was inserted from the bottom of reactor to collect gas and remaining solid. The active length (the distance between the bottom of the feeding tube and the top of the sampling probe) was of $1.2 \mathrm{~m}$. Due to the small size of the particles, their residence time was close to the gas residence time, that is about $2 \mathrm{~s}$.

Minimally handled char samples, in many cases in "button" form, as formed in the low-heating-rate charring crucibles, were stored in sealed glass vials, in a dessicator, and ground immediately before reactivity testing. Oxidative reactivity results were found to be very similar for samples tested within the first month after charring, and those freshly ground and tested 5 months after charring. Gasification reactivity tests were 
performed approximately 10 months after charring, using freshly ground samples. In all cases, chars were ground in an agate mortar but not sieved. However, in separate grinding and sieving tests, virtually the entire ground sample passed through a $250-\mu \mathrm{m}$ sieve.

\subsection{Oxidative reactivity measurements}

Non-isothermal oxidation kinetics were determined thermogravimetrically at $1 \mathrm{~atm}$ in a Netzsch STA 449C Jupiter simultaneous analyzer. Samples of $10 \pm 1 \mathrm{mg}$ were placed in an alumina crucible with $10.6 \mathrm{~mm}$ height and $6 \mathrm{~mm}$ ID The sample was first heated at $10^{\circ} \mathrm{C} / \mathrm{min}$ to a temperature of $100^{\circ} \mathrm{C}$, maintained at $100{ }^{\circ} \mathrm{C}$ for $20 \mathrm{~min}$, and finally heated to $800^{\circ} \mathrm{C}$ at $10^{\circ} \mathrm{C} / \mathrm{min}$. A helium flow of $0.08 \mathrm{slpm}$ was maintained during the initial ramp and the first $15 \mathrm{~min}$ of the $100^{\circ} \mathrm{C}$ period, after which the same flow rate of 12.5 vol.\% $\mathrm{O}_{2}$ in He was substituted. Good repeatability in the TGA traces was obtained, and the stability of mass before $\mathrm{O}_{2}$ introduction indicated the adequacy of the drying period. A representative TGA trace, for char HHR-T-290, is shown in Fig. 1(a).

The oxidation reactivity of the char, $r_{\mathrm{ox}}$, was determined from the mass measurements using Eq. (1). $r_{\mathrm{ox}}$ is the time derivative of the conversion, $X$. In this equation, $m_{\mathrm{i}}$ refers to the mass at the start of the $\mathrm{O}_{2}$ introduction, i.e. after the biomass has been dried at $100{ }^{\circ} \mathrm{C}$ for $15 \mathrm{~min}$. The ash mass, $m_{\text {ash }}$, was taken to be equal to the average mass over the temperature between 640 and $700{ }^{\circ} \mathrm{C}$. Eq. (1) was evaluated at selected temperatures between 400 and $600{ }^{\circ} \mathrm{C}$, with mass measurements averaged over $5{ }^{\circ} \mathrm{C}$ intervals to reduce noise.

$r_{\mathrm{ox}}=\left(\frac{d X}{d t}\right) ; \quad X \equiv \frac{m_{\mathrm{i}}-m(t)}{m_{\mathrm{i}}-m_{\mathrm{ash}}}$

It has been shown in previous work on carbon particle bed oxidation in a thermogravimetric analysis (TGA) apparatus with a similar temperature range and sample size (Salvador et al., 2003) that oxygen transfer limitations may slow the reaction. The results of char oxidation in the current work should not be taken as purely kinetically controlled; they nevertheless enable direct comparison between different samples.

\subsection{Gasification reactivity measurements}

Char gasification with steam took place isothermally in a thermogravimetric analysis device operating at atmospheric pressure (SETARAM Setsys coupled with steam generator Wetsys). Samples of $5 \pm 0.1 \mathrm{mg}$ were placed in the crucible of the thermobalance. This crucible was a cylinder of $2.5 \mathrm{~mm}$ height and $8 \mathrm{~mm}$ ID. The sample was heated at a rate of $24{ }^{\circ} \mathrm{C} /$ min to $800^{\circ} \mathrm{C}$ under a $\mathrm{N}_{2}$ gas flow of $0.05 \mathrm{slpm}$ until volatilization was complete. After the gasification temperature of $800{ }^{\circ} \mathrm{C}$ was reached and no further mass loss was observed, the gas was switched to a $\mathrm{H}_{2} \mathrm{O} / \mathrm{N}_{2}$ mixture ( 27 vol.\% $\mathrm{H}_{2} \mathrm{O}$, with an uncertainty below $4 \%$ ) with the same total
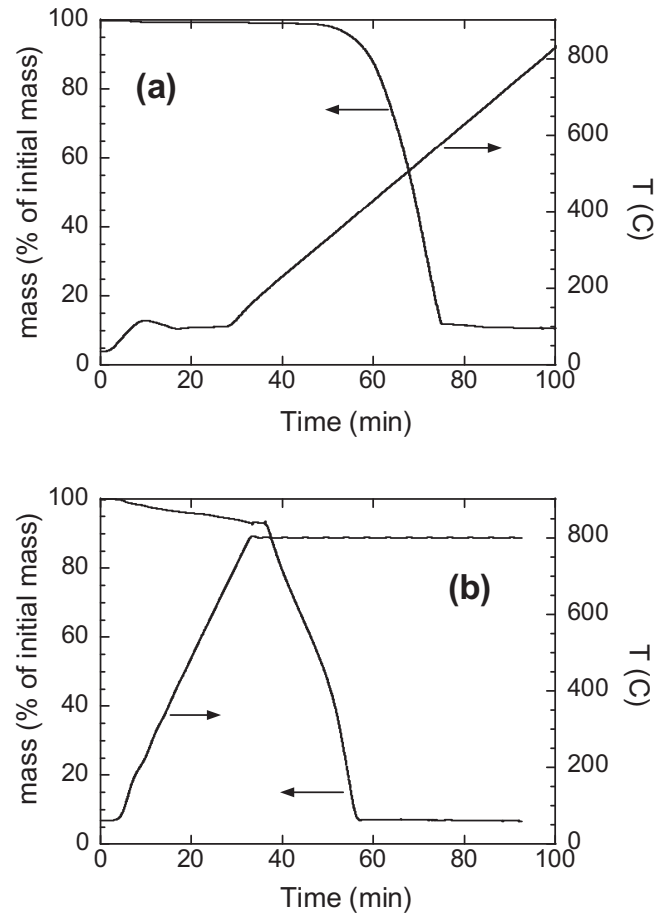

Fig. 1. Representative TGA mass and temperature profiles, for char HHR-T-290, for (a) oxidation; (b) gasification.

flow rate, and gasification occurred. A representative TGA trace, for char HHR-T-290, is shown in Fig. 1(b).

Similarly to the process for oxidation reactivity, the gasification reactivity, $r_{\text {gas }}$, was based on the measurements of mass loss versus time, as shown in Eq. (2).

$r_{\text {gas }}=\left(\frac{d X}{d t}\right) ; \quad X \equiv \frac{m_{\mathrm{i}}-m(t)}{m_{\mathrm{i}}-m_{\mathrm{f}}}$

In this expression, $m_{\mathrm{i}}, m(t)$ and $m_{\mathrm{f}}$ are the masses of char at the start of steam gasification (after heating in $\mathrm{N}_{2}$ ), at time $t$ and at the end of gasification respectively.

The average gasification reactivity $r_{\text {gas, integ }}$ was also defined between two stages of conversion $X_{1}$ and $X_{2}$ by:

$r_{\text {gas, integ }}=\frac{\int_{t_{x_{1}}}^{t_{x_{2}}} \frac{r_{g a s}(t) d t}{1-X(t)}}{t_{x_{2}}-t_{x_{1}}}$

Note that there is no standardized definition of reactivity. Here $X_{1}$ and $X_{2}$ are chosen to be $5 \%$ and $70 \%$. This choice allows a global reactivity to be obtained without taking into account the very beginning and the end of the reaction, during which the occurrence of specific phenomena may obscure the global trend.

Table 1

Charring conditions, fractional mass loss during charring on a dry basis, and codes for char samples.

\begin{tabular}{|c|c|c|c|c|c|}
\hline Sample code & $\begin{array}{l}\text { Heating rate } \\
\left({ }^{\circ} \mathrm{C} / \mathrm{min}\right)\end{array}$ & $\begin{array}{l}\text { Peak temperature and hold } \\
\text { time at peak temperature }\end{array}$ & $\begin{array}{l}\text { Ambient gas } \\
\text { during charring }\end{array}$ & Starting material & $\begin{array}{l}\text { Mass loss during charring, } \\
\text { dry basis (\%) }\end{array}$ \\
\hline LHR-1000-R & 33 & $1000^{\circ} \mathrm{C}$ for $60 \mathrm{~min}$ & $\mathrm{~N}_{2}$ & Raw willow & 80.4 \\
\hline LHR-1000-T-270 & 33 & $1000^{\circ} \mathrm{C}$ for $60 \mathrm{~min}$ & $\mathrm{~N}_{2}$ & $270^{\circ} \mathrm{C}$ torrefied willow & 73.4 \\
\hline LHR-1000-T-290 & 33 & $1000^{\circ} \mathrm{C}$ for $60 \mathrm{~min}$ & $\mathrm{~N}_{2}$ & $290{ }^{\circ} \mathrm{C}$ torrefied willow & 67.8 \\
\hline LHR-850-R & 33 & $850^{\circ} \mathrm{C}$ for $30 \mathrm{~min}$ & $\mathrm{Ar}$ & Raw willow & 84.1 \\
\hline LHR-850-T-290 & 33 & $850^{\circ} \mathrm{C}$ for $30 \mathrm{~min}$ & $\mathrm{Ar}$ & $290^{\circ} \mathrm{C}$ torrefied willow & 65.6 \\
\hline HHR-R & $>30,000$ & $900^{\circ} \mathrm{C}$ for approximately $0.03 \mathrm{~min}$ & $\mathrm{~N}_{2}$ & Raw willow & ${ }^{*}$ \\
\hline HHR-T-270 & $>30,000$ & $900^{\circ} \mathrm{C}$ for approximately $0.03 \mathrm{~min}$ & $\mathrm{~N}_{2}$ & $270^{\circ} \mathrm{C}$ torrefied willow & * \\
\hline HHR-T-290 & $>30,000$ & $900{ }^{\circ} \mathrm{C}$ for approximately $0.03 \mathrm{~min}$ & $\mathrm{~N}_{2}$ & $290{ }^{\circ} \mathrm{C}$ torrefied willow & ${ }^{*}$ \\
\hline
\end{tabular}

Mass loss could not be determined in the high-heating-rate drop tube experiments. 
Table 2

Ultimate analysis of biomass, torrefied biomass, and char samples; mass percent on an as-received basis (after drying, milling, and storage).

\begin{tabular}{llllr}
\hline Sample Code & $\mathrm{C}$ & $\mathrm{H}$ & $\mathrm{N}$ & \multicolumn{1}{l}{$\mathrm{S}$} \\
\hline Raw willow (R) & 48.28 & 5.86 & 0.32 & $<0.01$ \\
Torrefied willow, $270^{\circ} \mathrm{C}(\mathrm{T}-270)$ & 54.29 & 5.57 & 0.38 & $<0.01$ \\
Torrefied willow, $290^{\circ} \mathrm{C}(\mathrm{T}-290)$ & 58.38 & 5.55 & 0.38 & $<0.01$ \\
LHR-1000-R & 87.65 & 0.81 & 0.48 & 0.02 \\
LHR-1000-T-270 & 85.46 & 0.62 & 0.39 & 0.04 \\
LHR-1000-T-290 & 89.89 & 0.61 & 0.40 & 0.02 \\
LHR-850-R & 88.01 & 1.23 & 0.53 & $<0.01$ \\
LHR-850-T-290 & 89.66 & 1.29 & 0.55 & $<0.01$ \\
HHR-R & 73.77 & 1.20 & 0.56 & 0.02 \\
HHR-T-270 & 86.56 & 1.20 & 0.52 & 0.01 \\
HHR-T-290 & 85.85 & 1.19 & 0.55 & 0.03 \\
\hline
\end{tabular}

Table 3

Proximate analysis of biomass and torrefied biomass samples, mass percent. See Table 1 for an explanation of the sample codes.

\begin{tabular}{cllll}
\hline Sample description & $\begin{array}{l}\text { Moisture } \\
\text { content }\end{array}$ & $\begin{array}{l}\text { Volatile } \\
\text { content }\end{array}$ & $\begin{array}{l}\text { Fixed } \\
\text { carbon }\end{array}$ & $\begin{array}{l}\text { Ash } \\
\text { content }\end{array}$ \\
\hline $\begin{array}{l}\text { Raw willow (R) } \\
\text { Torrefied willow, } \\
270{ }^{\circ} \mathrm{C}(\mathrm{T}-270)\end{array}$ & 4.5 & 77.4 & 16.9 & 1.23 \\
$\begin{array}{c}\text { Torrefied willow, } \\
290{ }^{\circ} \mathrm{C}(\mathrm{T}-290)\end{array}$ & 2.7 & 70.8 & 24.8 & 1.63 \\
\hline
\end{tabular}

Preliminary experiments and calculations have shown that under the operating conditions $\left(T=750-900^{\circ} \mathrm{C}\right.$; particle size $<50 \mu \mathrm{m}$; sample mass $=5 \mathrm{mg}$ ), the intrinsic kinetics regime was reached and that there were no limitations by heat or mass transfer (Nocquet, 2009).

The repeatability of the experiments was checked by repeating each test. The relative difference of average reactivity between two tests was always below $5 \%$.

\subsection{Char characterization}

Ultimate and proximate analyses were performed. The $\mathrm{C}, \mathrm{H}, \mathrm{N}$ and $\mathrm{S}$ contents were determined according to a British Standard method (BS EN 15104, 2011). O content was obtained by difference. Proximate analyses were carried out according to the European standards (DD CEN/TS, 2004a, 2004b, 2005).

The Scanning Electron Microscopy (SEM) equipment used for solid particles observation was a Philips XL30.

\section{Characteristics of biomass, torrefied biomass, and chars}

Results of the ultimate analysis of willow, torrefied willow, and char, and of the procimate analysis of willow and torrefied willow are shown in Tables 2 and 3, respectively. As seen by Bridgeman et al. (2008), both torrefaction and charring reduced $\mathrm{H}$ and $\mathrm{O}$ content. Torrefaction also reduced moisture and volatiles content, while ultimate analyses were not performed for chars because of the limited sample size available. Fig. 2 shows the particle size distribution, obtained by sieving, of the raw and torrefied biomass after milling and immediately before charring. Clearly, the two torrefied samples show very different size distributions than the raw willow sample, with much larger fractions of the mass in the small size ranges. This result is in agreement with the findings of previous studies (Arias et al., 2008; Almeida et al., 2009). In contrast to previous work (Bridgeman et al., 2010) the increase in torrefaction temperature between 270 and $290{ }^{\circ} \mathrm{C}$ did not lead to an increase in fractions in the smallest size ranges $(<50 \mu \mathrm{m})$. As the amount of biomass in each ball mill batch was not tightly con-
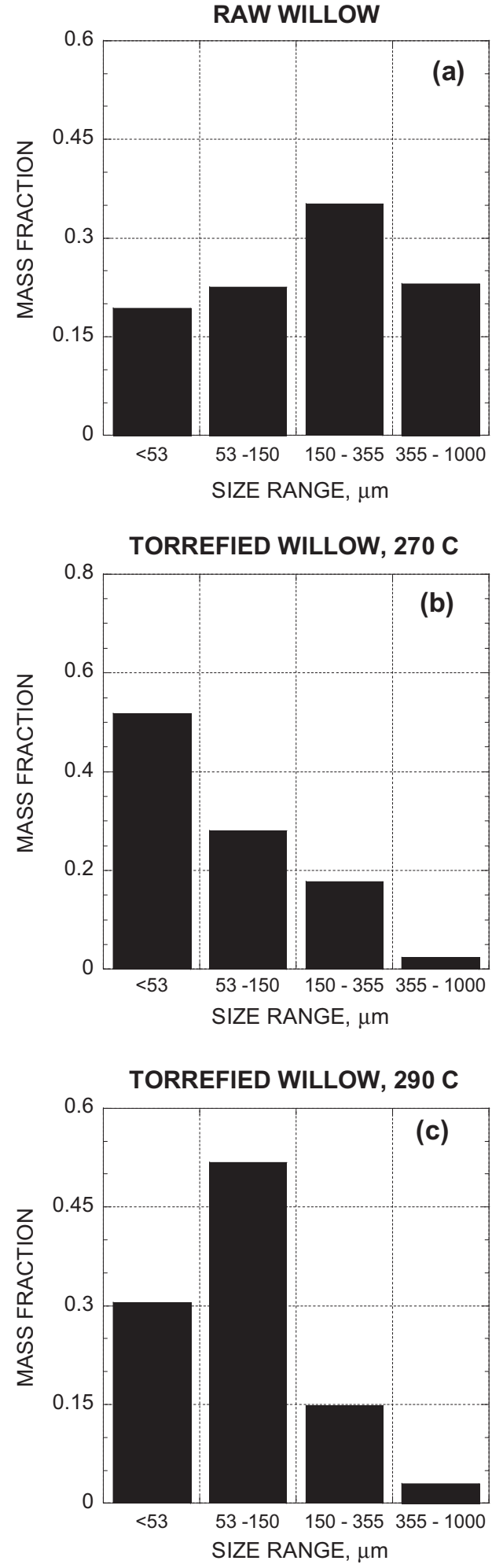

Fig. 2. Particle size distribution before charring.

trolled, this result may simply arise from slightly different grinding conditions.

The improved fluidization of torrefied particles is generally associated with an absence of little thread-like fibers at the edge of milled torrefied particles, provided that the treatment conditions were severe enough. This seems to be confirmed by SEM observations (Supplementary material): particles of raw biomass have numerous needle-like fibers at their edges, and particles 

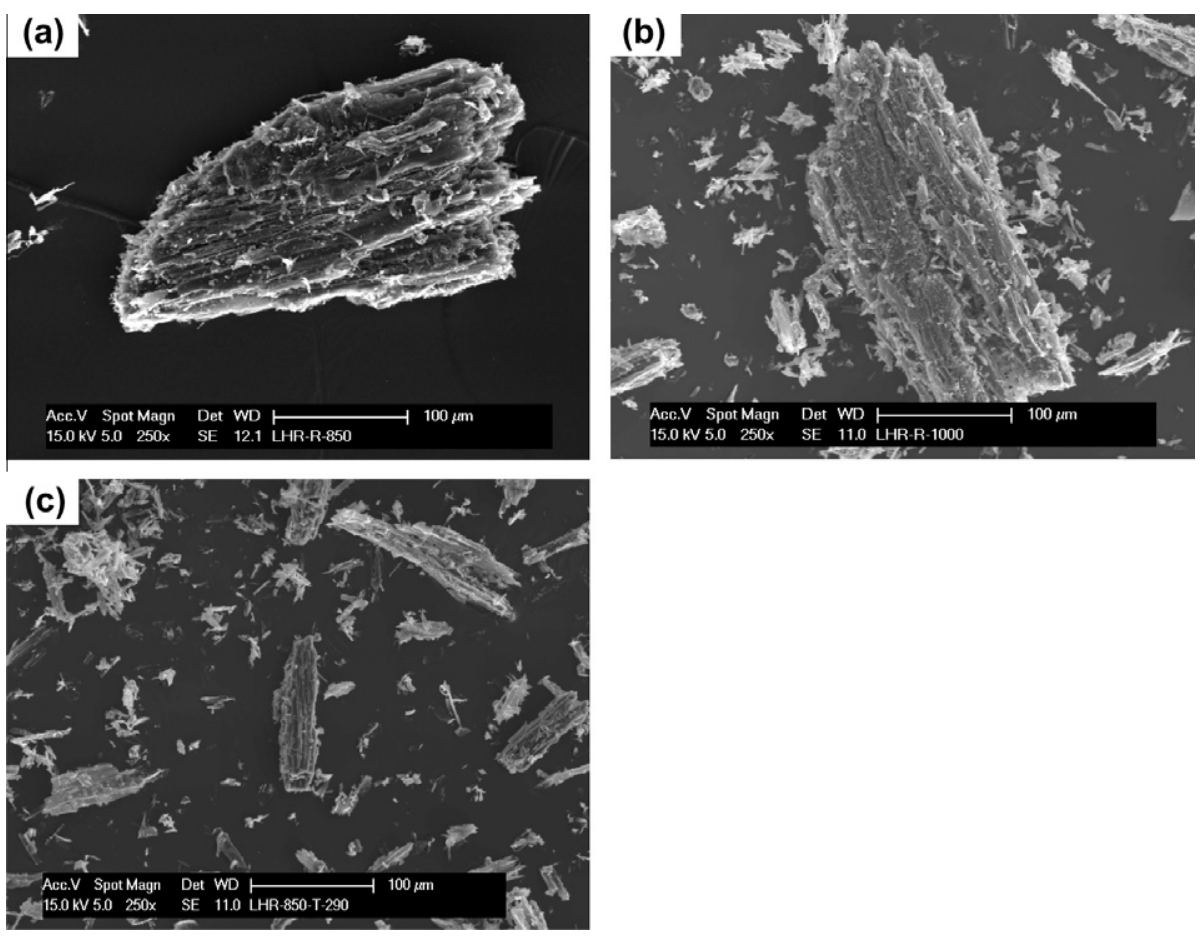

Fig. 3. SEM images of chars: (a) LHR-850-R; (b) LHR-850-T-290; (c) LHR-1000-R.

torrefied at $270{ }^{\circ} \mathrm{C}$ retain some such fibers. In contrast, these fibers appear to be completely absent on particles torrefied at $290^{\circ} \mathrm{C}$.

Regarding chars, in agreement with Cetin et al. (2004), the pyrolysis heating rate appears to have great influence on structure under the conditions explored. Regardless of the pyrolysis temperature, the presence or absence of torrefaction, and the particle size, almost all particles from low-heating-rate chars kept the fibrous structure of the initial wood. This is illustrated in Fig. 3a-c; under these conditions there were also some smaller low-aspectratio particles with irregular morphologies. In contrast, for highheating-rate chars, particles exhibited either a deformed fibrous structure (dominant for chars from raw biomass, as shown in Fig. 4a) or an exploded spherical shell structure (dominant for chars from torrefied biomass, as shown in Fig. 4b and c). As highlighted in Fig. $4 \mathrm{~d}$ and e, macropores in the size range $0.5-50 \mu \mathrm{m}$ could be seen on the exterior of the high-heating-rate chars. These pores appeared in high-heating-rate chars from both torrefied and raw biomass, but no pores were visible in similar close-up images of the low-heating-rate chars.

As explained in the introduction, torrefaction was expected to impact the structure of high-heating-rate chars by reducing the deformation of biomass structures during rapid volatiles release in pyrolysis. No significant effect was anticipated on the structure of low-heating-rate chars, and this expectation was borne out in the SEM photographs shown for representative cases in Fig. 3a and b (raw), and Fig. 3c (torrefied). Hence, as expected, although particles of low-heating-rate char produced from torrefied biomass appeared to be generally smaller than those from raw biomass, their structure remained fibrous, as for other low-heating-rate chars.

In contrast, pretreatment by torrefaction had a dramatic impact on the structure of high-heating-rate chars, but not in the expected way. It had been anticipated that, due to lower volatiles release, the structures of chars from torrefied samples would more closely resemble those of the original biomass than would those of the chars produced from raw biomass. Instead, as shown in Fig. $4 \mathrm{~b}$ and c, the torrefied chars consist almost entirely of low-aspect-ratio particles with no resemblance to the original biomass particles.
The raw willow high-heating-rate chars consist mainly of large, distorted fibrous particles that retain the basic shape of the original biomass particles (Fig. 4a).

The dominance of smaller sizes in the distribution of torrefied biomass samples may explain the difference in structure. Avila et al. (2011) found that small particles $(\sim 100 \mu \mathrm{m})$ showed significantly more loss of initial biomass structures during charring than large particles $(\sim 800 \mu \mathrm{m})$ did, for certain biomass types in intermediate-heating-rate experiments. This appears to be logical: the gas release occurs more slowly in larger particles due to heat transfer limitations and hence the gas can be released without destroying the initial solid structure. Thus, the smaller particles that predominate the torrefied wood samples in the current study would produce the exploded sphere structures that are most prominent in Fig. 4b and c, while the larger particles constituting the majority of raw biomass particles produced deformed fibrous char particles instead (Fig. 4a). Thus it is clear that the initial particle size has a major influence on the subsequent char structure, perhaps even greater than the impact of the amount of volatiles released.

\section{Reactivity results and discussion}

\subsection{Oxidation results}

Oxidative reactivity results are shown in Fig. 5. In several cases, duplicate data points are displayed, showing excellent repeatability; these correspond to TGA experiments performed on different days, sometimes more than four months apart. Arrhenius parameters fit to the data points shown are reported in Table 4. The char reactivities show distinctly non-Arrhenius behavior over the temperature range of interest, and their Arrhenius parameters depend strongly on the choice of temperature interval.

The results obtained in the current study (raw biomass curves from Fig. 5a-c) confirm those from previous studies showing that higher-heating-rate chars were more reactive than low-heatingrate chars from the same solid fuel (Di Blasi, 2009; Guerrero 

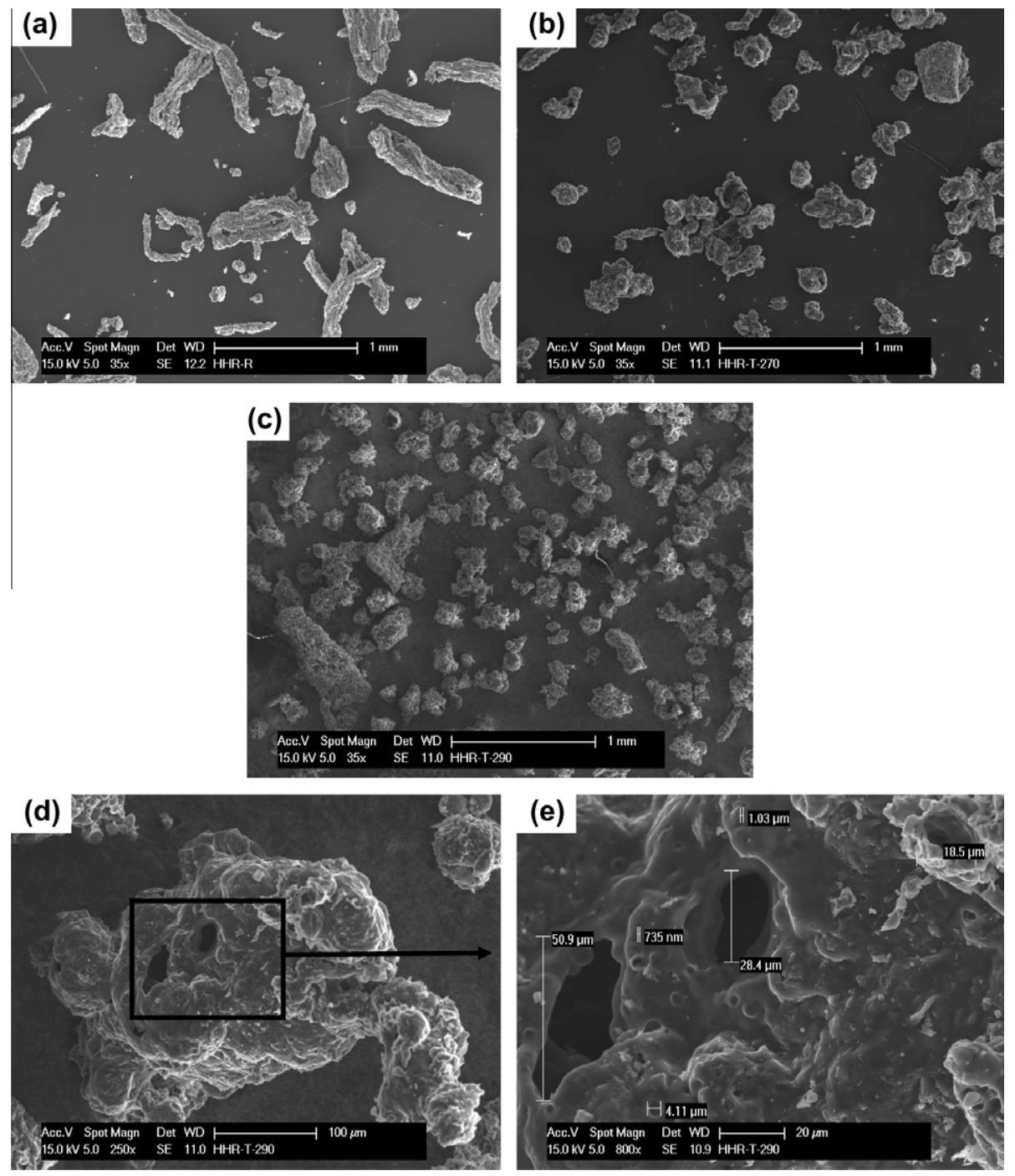

Fig. 4. SEM images of chars: (a) HHR-R; (b) HHR-T-270; (c-e) HHR-T-290; image (e) is a zoom of the rectangular zone shown in image (d).

et al., 2005; Dall'Ora et al., 2008), and higher char formation temperatures lead to lower reactivities (Dall'Ora et al., 2008). The same trends are seen in the torrefied biomass data, by comparing the T290 curves from Fig. 5a-c. Differences between HHR chars and LHR chars are greater than those between LHR chars with different peak preparation temperatures.

Fig. 5 shows the differences between oxidation reactivities of chars from torrefied vs. raw biomass under the same charring conditions. The charring method has a distinct and consistent effect on the impact of torrefaction on reactivity. When chars were formed with low heating rates and a long residence time at a high final temperature (LHR-1000 conditions; Fig. 5a), torrefaction had little effect on char reactivity, reducing it by only about $5-10 \%$. At the milder low-heating-rate conditions (LHR-850 conditions; Fig. 5b), chars from torrefied wood were less reactive by about a factor of 1.5 than those from raw wood. With high-heating-rate char formation (Fig. 5c), torrefaction had an even larger effect. Very little difference was observed between the chars from torrefied samples prepared at two different temperatures, but the two torrefied samples produced chars with substantially lower reactivities than the char from the raw willow. This result is consistent with findings for high-heating-rate chars produced in a pyroprobe (Bridgeman, 2008). The torrefied and non-torrefied high-heating-rate chars differ in reactivity by a factor of about two.
The reactivity vs. temperature curves indicates a roughly linear relationship at lower temperature, followed by a portion with reduced apparent activation energy, likely due to the onset of transport limitations. The temperature sensitivity of the rates can also be seen in Table 4. Oxidation had higher activation energies for chars from torrefied than from raw biomass, and higher activation energies for LHR than for HHR chars. In this table, the Arrhenius fit is applied over a fixed conversion range that extends into the transport-limited regime. This leads to considerably lower values of activation energy than those reported by Di Blasi (2009).

\subsection{Gasification results}

Gasification reactivity was tested in isothermal mode at a temperature of $800^{\circ} \mathrm{C}$.

The average reactivity between $5 \%$ and $70 \%$ of conversion was the parameter used to compare samples in Fig. 6a. Reactivities differing by a factor of 9 can be seen, ranging from about $26 \% / \mathrm{min}$ (for the high-heating-rate raw char HHR-R), to about 3\%/min (for the low-heating-rate torrefied char LHR-850-T-290). For both low and high heating rate, the reactivity of char from torrefied biomass was lower than that char from raw biomass. This result is consistent with findings by Couhert et al. (2009) for gasification in an entrained flow reactor. Quantitatively, for the high-heating-rate 

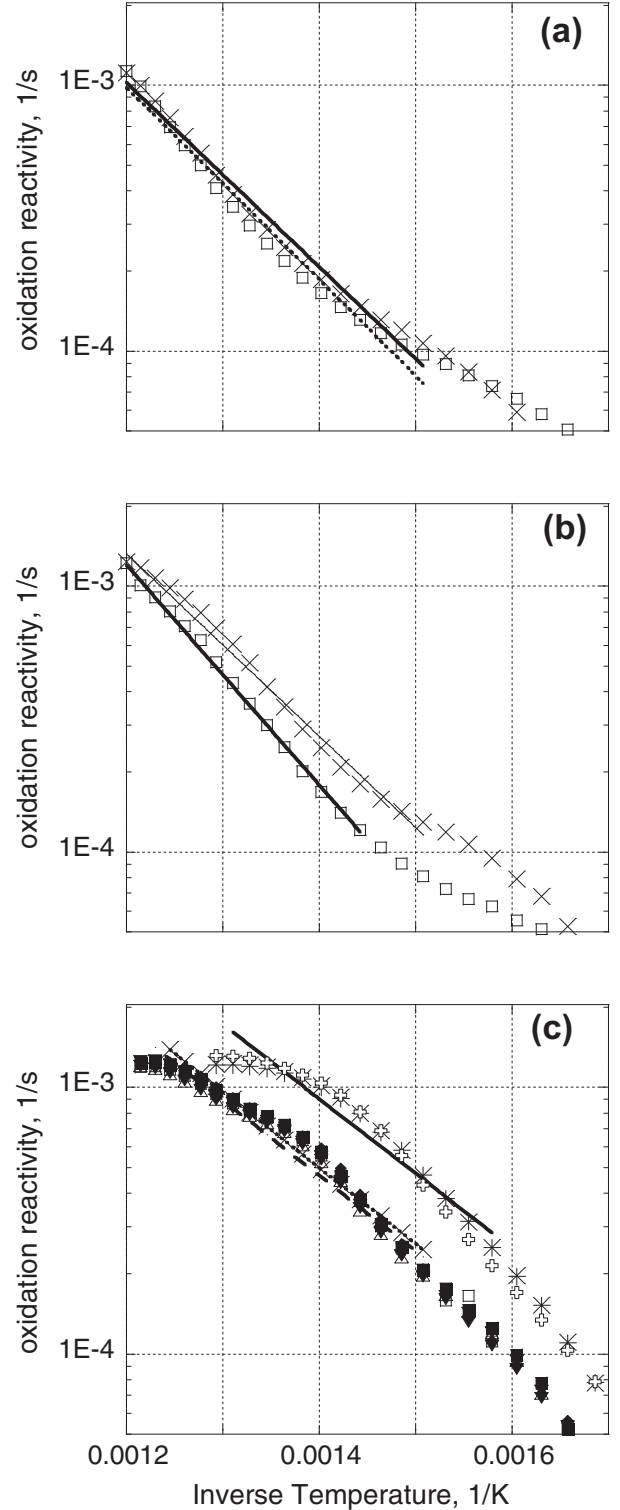

Fig. 5. Oxidative reactivity Arrhenius plots. Lines show the range over which the Arrhenius fits of Table 4 were obtained. (a) chars produced at low heating rates to $100{ }^{\circ} \mathrm{C}$. exes: char from raw biomass (LHR-1000-R); squares: char from torrefied biomass (LHR-1000-T-290). (b) chars produced at low heating rates to $850^{\circ} \mathrm{C}$. exes: char from raw biomass (LHR-850-R); squares: char from torrefied biomass (LHR850-T-290). (c) chars produced at high heating rates. Crosses and exes: char from raw biomass (HHR-R); triangles: char from biomass torrefied to $270{ }^{\circ} \mathrm{C}$ (HHR-T270); squares: char from biomass torrefied to $290^{\circ} \mathrm{C}$ (HHR-T-290)

chars, the average reactivity is three times lower with torrefaction pretreatment. For low-heating-rate chars (LHR-850), the trend was less marked, with an average reactivity of a factor of 1.5 lower with torrefaction pretreatment.

In agreement with previous findings (Cetin et al., 2004; Mermoud et al., 2006), the higher the pyrolysis heating rate, the higher the reactivity. Hence, the char produced from raw biomass at high heating rate had a five times higher reactivity than the corresponding char produced at a low heating rate. The high-heating-rate chars' porous structure, which can be observed in Fig. $5 c$ and d, is generally assumed to be responsible for this higher reactivity.

As shown in Fig. 6b, all samples exhibited very different kinetics of conversion but similar shapes of the curve of conversion versus time. Hence, as can be seen in Fig. 6c, the gasification rate was roughly constant at low levels of conversion, then underwent a sig-
Table 4

Arrhenius parameters for oxidative reactivity; see Table 1 for an explanation of sample codes. $R=A \exp \left(-E_{\mathrm{A}} /(R T)\right)$, where $T$ is in Kelvin.

\begin{tabular}{lccll}
\hline Sample code & $\begin{array}{l}A \\
\left(\mathrm{sec}^{-1}\right)\end{array}$ & $E_{\mathrm{A}}(\mathrm{kJ} / \mathrm{mole})$ & $\begin{array}{l}\text { Temperature } \\
\text { range for } \\
\text { Arrhenius fit } \\
\left({ }^{\circ} \mathrm{C}\right)\end{array}$ & $\begin{array}{l}\text { Conversion, } X, \\
\text { over range of } \\
\text { Arrhenius fit }\end{array}$ \\
\hline LHR-1000-R & 14.7 & 66.1 & $390-580$ & $5-70$ \\
LHR-1000-T-290 & 21.4 & 69.1 & $390-590$ & $5-70$ \\
LHR-850-R & 17.6 & 65.7 & $390-570$ & $5-70$ \\
LHR-850-T-290 & 112 & 79.1 & $420-580$ & $5-70$ \\
HHR-R & 7.44 & 53.2 & $360-490$ & $5-70$ \\
HHR-T-270 & 4.15 & 54.0 & $390-540$ & $5-70$ \\
HHR-T-290 & 4.93 & 54.4 & $390-530$ & $5-70$ \\
\hline
\end{tabular}

nificant increase starting at a conversion of about $40 \%$ for highheating-rate raw chars and at a conversion of about $60 \%$ for the other chars. Finally, the gasification rate sharply decreased at the very end of the reaction. This rate evolution characterized by an increase of the rate at high conversions is in agreement with previous findings on wood chars (Marquez-Montesinos et al., 2002; Dupont et al., 2011) and is probably related to catalytic effects of inorganic elements. The qualitative similarity of the conversion curves suggests that the global gasification mechanism was not affected by the torrefaction pretreatment.

\subsection{Discussion}

Both oxidative and gasification kinetics show the same qualitative effects of pretreatment by torrefaction and of charring conditions: reactivity was lower for chars from torrefied willow, and lower for chars created under low heating rate conditions.

Quantitatively, for the higher-heating-rate chars, pretreatment by torrefaction reduced both oxidative and gasification reactivity by factors of two to three, as indicated above. For the low-heating-rate chars with less severe charring conditions (LHR-850), the effect of pretreatment by torrefaction is smaller (reduction by about a factor of 1.5). For the low-heating-rate chars with severe charring conditions (LHR-1000), which is tested only under oxidative conditions, the effect of pretreatment by torrefaction on reactivity is minimal.

To the extent that they were studied here, the choice of torrefaction conditions had little impact on char reactivity. High-heating-rate chars prepared from samples torrefied at different temperatures showed essentially the same oxidative reactivities. The effect of torrefaction conditions was not tested under gasification conditions or for low-heating-rate chars.

It is possible to speculate on possible reasons for impact of torrefaction on reactivity. For formation under HHR conditions, the smaller particles associated with torrefied samples would heat up faster and thus have longer residence times at peak temperature. This difference could lead to lower reactivity via thermal annealing (Shim and Hurt, 2000). Reduced volatiles content could reduce pore formation in HHR chars and thus lead to lower surface areas for torrefied biomass, offering an alternative explanation for the observed differences.

From a process viewpoint, a simple calculation based on the different Arrhenius parameters implies that the temperature of a high-heating-rate gasification reactor processing torrefied biomass would need to be more than $100{ }^{\circ} \mathrm{C}$ higher to achieve the same level of conversion as would be achieved for raw biomass. Similar observations imply longer burn-out time requirements for torrefied materials. Hence, using torrefied products rather than raw biomass in entrained flow reactors or combustors may significantly impact process control and design. However, as expected, oxidative reactivities of chars from torrefied materials are higher than those from bituminous coal (Zhang et al., 2008; Jones et al., 
(a)

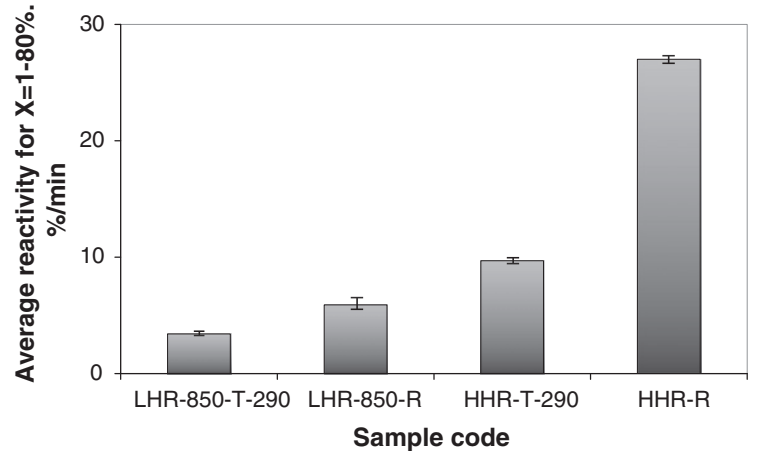

(b)

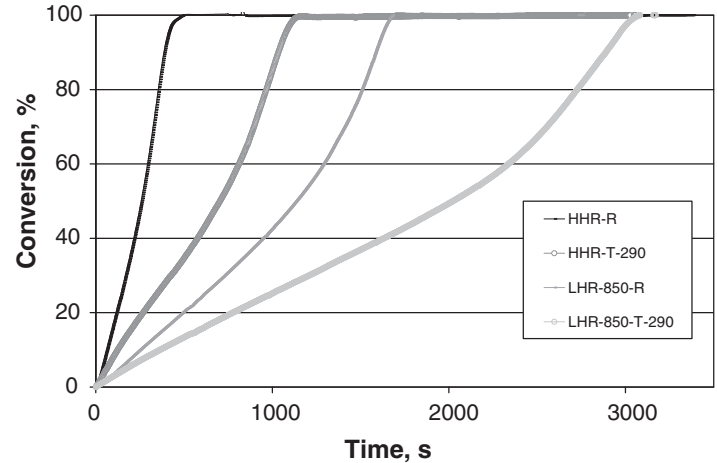

(c)

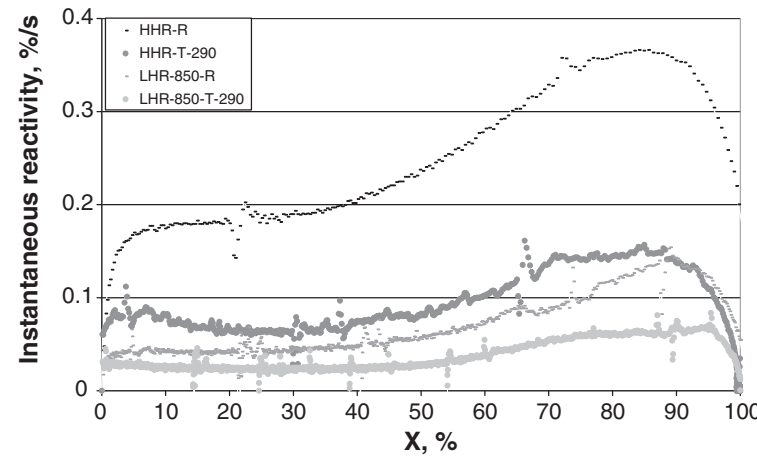

Fig. 6. Gasification reactivity: (a) Average gasification reactivity of chars for conversion between 5 and $70 \%$ (b) Conversion of chars versus time (c) Instantaneous gasification reactivity.

2004) which means that burnout times or reactor temperatures selected for coal should be adequate even for torrefied biomass.

\section{Conclusions}

Torrefied biomass is viewed as an attractive feedstock for combustion and gasification, mainly because of its advantages over raw biomass in storage, handling, and transportation. The current study has found lower combustion and gasification reactivities for chars produced from torrefied biomass fuels, in comparison to those produced from the same raw biomass fuels, especially under highheating-rate charring conditions. These char reactivity differences imply that combustor and gasifier design or operating conditions may need to be adjusted when switching from a raw biomass to a torrefied biomass fuel. The causes of the reactivity differences can be resolved only through further research.

\section{Acknowledgements}

We acknowledge the financial assistance of Cornell's ADVANCE Center, funded by NSF Grant \#0547373, and of UK Engineering and
Physical Sciences Research Council Grant EP/HO48839. EMF thanks Dr. Xiaomian Baxter, Univ. of Leeds for her help.

\section{Appendix A. Supplementary data}

Supplementary data associated with this article can be found, in the online version, at http://dx.doi.org/10.1016/ j.biortech.2012.05.109.

\section{References}

Almeida, G., Commandré, J.M., Duplan, J.L., Dupont, C., Leboutte, D., Melkior, T., Perré, P., Rémond, R., Rousset, P., Sajet P., Sanz-Garcia, E., 2009. From biomass torrefaction to solid injection in pressurized gasifier: model and experiences, 17th European Conference on Biomass, Hamburg.

Arias, B., Pevida, C., Fermoso, J., Plaza, M.G., Rubiera, F., Pis, J.J., 2008. Influence of torrefaction on the grindability and reactivity of woody biomass. Fuel Process. Technol. 89, 169-175.

Avila, C., Pang, C.H., Wu, C.T., Lester, E., 2011. Morphology and reactivity characteristics of biomass particles. Bioresour. Technol. 102, 5237-5243.

Bridgeman, T., 2008. Enhancing the Fuel Properties of Solid Biofuels by Torrefaction, University of Leeds, PhD Thesis.

Bridgeman, T.G., Jones, J.M., Shield, I., Williams, P.T., 2008. Torrefaction of reed canary grass, wheat straw and willow to enhance solid fuel qualities and combustion properties. Fuel 87, 844-856.

Bridgeman, T.G., Jones, J.M., Williams, A., Waldron, D.J., 2010. An investigation of the grindability of two torrefied energy crops. Fuel 89, 3911-3918.

BS EN 15104:2011 "Solid biofuels. Determination of total content of carbon, hydrogen and nitrogen. Instrumental methods".

Cetin, E., Moghtaderi, B., Gupta, R., Wall, T.F., 2004. Influence of pyrolysis conditions on the structure and gasification reactivity of biomass chars. Fuel, 2139-2150.

Chen, W.-H., Cheng, W.-Y., Lu, K.-M., Huang, Y.-P., 2011. An evaluation on improvement of pulverized biomass property for solid fuel through torrefaction. Appl. Energy 88, 3636-3644.

Chew, J.J., Doshi, V., 2011. Recent advances in biomass pretreatment - torrefaction fundamentals and technology. Renew. Sust. Energy Rev. 15, 4212-4222.

Commandré, J.-M., Salvador, S., VanDeSteene, L., Gadiou, R., 2005. The formation and reduction of NO during the combustion of powdered petroleum coke - the case of cement plant precalciner conditions. Combust. Sci. Technol. 177, 579611.

Costa, M., Silva, P., Azevedo, J.L.T., 2003. Measurements of gas species, temperature, and char burnout in a low NOx pulverized-coal-fired utility boiler. Combust. Sci. Technol. 175, 271-289.

Couhert, C., Salvador, S., Commandré, J.M., 2009. Impact of torrefaction on syngas production from wood. Fuel 88, 2286-2290.

Dall'Ora, M., Jensen, P.A., Jensen, A.D., 2008. Suspension combustion of wood: influence of pyrolysis conditions on char yield, morphology, and reactivity. Energy Fuels 22, 2955-2962.

DD CEN/TS 14774-3: 2004a, Solid biofuels, Methods for the determination of moisture content - Oven dry method - Part 3: Moisture in general analysis sample.

DD CEN/TS 15148:2005, Solid biofuels, Method for the determination of the content of volatile matter

DD CEN/TS 14775:2004b, Solid biofuels, Method for the determination of ash content.

Di Blasi, C., 2009. Combustion and gasification rates of lignocellulosic chars. Prog. Energy Combust. Sci. 49, 2658-2671.

Dupont, C., Commandré, J.M., Gauthier, P., Boissonet, G., Salvador, S., Schweich, D. 2008. Biomass pyrolysis experiments in an analytical entrained flow reactor between 1073 and $1273 \mathrm{~K}$. Fuel 87, 1155-1164.

Dupont, C., Nocquet, T., Da Costa Jr., J.A., Verne-Tournon, C., 2011. Kinetic modelling of steam gasification of various woody biomass chars: influence of inorganic elements. Bioresour. Technol. 102, 9743-9748.

Guerrero, M., Ruiz, M.P., Alzueta, M.U., Bilbao, R., Millera, A., 2005. Pyrolysis of eucalyptus at different heating rates: studies of char characterization and oxidative reactivity. J. Anal. Appl. Pyrolysis 74, 307-314.

Jones, J.M., Pourkashanian, M., Williams, A., Rowland, L., Zhu, W., Thomas, K.M. 2004. Conversion of char nitrogen to NO during combustion. J. Energy Inst. 77, 82-89.

Marquez-Montesinos, F., Cordero, T., Rodriguez-Mirasol, J., Rodriguez, J.J., 2002. $\mathrm{CO}_{2}$ and steam gasification of grapefruit skin char. Fuel 81, 423-429.

Mehrabian, R., Scharler, R., Obernberger, I., 2011. Effects of pyrolysis conditions on the heating rate in biomass particles and applicability of TGA kinetic parameters in particle thermal conversion modeling. Fuel 93, 567-575.

Mermoud, F., Salvador, S., Van de Steene, L., Golfier, F., 2006. Influence of the pyrolysis heating rate on the steam gasification rate of large wood char particles. Fuel 85, 1473-1482.

Nocquet, T.,2009. Rapport - Détermination d'un modèle cinétique de vapogazéification de différentes biomasses forestières à l'aide d'essais en thermobalance, CEA Grenoble.

Repellin, B., Govin, A., Rolland, M., Guyonnet, R., 2010. Energy requirement for fine grinding of torrefied wood. Biomass Bioenergy 34, 923-930. 
Salvador, S., Commandré, J.M., Stanmore, B., 2003. Reaction rates for the oxidation of highly sulphurised petroleum cokes: the influence of thermogravimetric conditions and some coke properties. Fuel 82, 715-720.

Shim, H.S., Hurt, R.H., 2000. Thermal annealing of chars form diverse organic precursors under combustion-like conditions. Energy Fuels 14, 340-348.

Skeen, S.A., Kumfer, B.M., Axelbaum, R.L., 2010. Nitric oxide emissions during coal and coal/biomass combustion under air-fired and oxy-fuel conditions. Energy Fuels 24, 4144-4152.

Svoboda, K., Porohely, M., Hartman, M., Martinec, J., 2009. Pretreatment and feeding of biomass for pressurized entrained flow gasification. Fuel Process. Technol. 90, 629-635.
Tillman, D.A., 2000. Biomass cofiring: the technology, the experience, the combustion consequences. Biomass Bioenergy 19, 365-384.

Van de Steene, L., Salvador, S., Charnay, G., 2000. Controlling powdered fuel combustion at low temperature in a new entrained flow reactor. Combust. Sci. Technol. 159, 255-279.

Zhang, S.-Y., Lu, J.-F., Zhang, J.-S., Yue, G.-X., 2008. Effect of pyrolysis intensity on the reactivity of coal char. Energy Fuels 22, 3213-3221.

Zhu, W., Song, W., Lin, W., 2008. Effect of the coal particle size on pyrolysis and char reactivity for two types of coal and demineralized coal. Energy Fuels 22, 24822487. 